\title{
Comparative Education in Brazil: understanding the field of research from the periodization topic: Contributions methodologies of Comparative Education
}

\begin{abstract}
Aguilar, Luis Enrique
Catedrático de la Facultad de Educación de la Universidad Estatal de Campinas, Investigador del Departamento de Administración, Políticas y Sistemas

Educativos, Laboratorio de Políticas Públicas y Planificación Educativa. Miembro de la Sociedad Brasileña de Educación Comparada. luis.aguilar@merconet.com.br

Spaolonzi Queiroz Assis, Ana Elisa Profesor de la Facultad de Educación de la Universidad Estatal de Campinas, Investigador del Departamento de Administración, Políticas y Sistemas Educativos, Laboratorio de Políticas Públicas y Planificación Educativa. Miembro de la Sociedad Brasileña de Educación Comparada. anaelisasqa@gmail.com
\end{abstract}

\section{Resumen}

Este texto tiene como objetivo reconstruir la trayectoria de la educación comparada en Brasil utilizando el concepto de línea de tiempo para identificar elementos estructurales en el surgimiento y la reconfiguración de este campo de estudio. La perspectiva histórica de la línea de tiempo nos permite utilizar dos características adicionales: a) la reconstrucción del escenario en el que surgen las producciones intelectuales; y simultáneamente b) identificar cómo aparecen los temas, problemas y objetos de investigación, ya sea en una asociación homogénea o no. Estos elementos nos permiten asociar métodos comparativos e históricos para reconocer la influencia supranacional y suprarregional, determinando la configuración de lo que se entiende por educación comparada en Brasil. El texto distingue siete momentos diferentes para el área educativa comparativa brasileña, que son: (1) el estudio de la estructura y el funcionamiento de la educación de sistemas europea y norteamericana; (2) la influencia pionera de la UNESCO en la producción de publicaciones anuales; (3) la priorización de las prácticas educativas; (4) la influencia de las relaciones supranacionales; (5) el enfoque en las políticas públicas educativas; (6) nuevo ciclo de influencia supranacional; (7) (re) definición del anclaje teórico, metodológico y epistemológico de la educación comparada. En el último cuarto de siglo, se puede decir que hay un resurgimiento de la Educación Comparada en Brasil y la región, que puede estar asociada a fuertes influencias históricas, aquí reconstruidas por la periodización.

\section{Abstract}

This text aims to reconstruct the trajectory of comparative education in Brazil using the timeline concept to identify structural elements in the emergence and reconfiguration of this field of study. The timeline historical perspective allows us to use two additional features: a) the reconstruction of the scenario in which emerge the intellectual productions; and simultaneously b) identify how themes, issues and research objects appears, whether in a homogeneous association or not. These elements allow us to associate comparative and historical methods to recognize the supranational and supra-regional influence, determining the configuration of what is meant by comparative education in Brazil. The text distinguishes seven different moments for the Brazilian comparative educational area, which are: (1) the study of the structure and functioning of European and North American systems education; (2) the UNESCO's pioneering influence on the production of annuals; (3) the prioritization of educational practices; (4) the influence of supranational relations; (5) the focus on educational public policies; (6) new cycle of supranational influence; (7) (re)definition of the theoretical, methodological and epistemological anchorage of comparative education. In the last quarter century, it can be said that there is a resurgence of Comparative Education in Brazil and the region, which may be associated with strong historical influences, here reconstructed by periodization.

Palabras clave: educación comparada; Periodización; Políticas Públicas Educativas; Brasil; historia de la educación.

Keywords: Comparative education; Periodization; Educational Public Policies; Brazil; history of education. 


\section{INTRODUCTION}

The periodization in the comparative analysis always refers us to the strict relations between comparative and historical method. We use this relation to weave some reflections from the concept of cleavages (LIPSET; ROKKAN, 1967) ${ }^{1}$, here understood as divisions or ruptures that allows the inclusion of the periodization concept in the comparative analysis, as well as the concept of sequence to recognize transformations, changes of focus or interest to contribute to the reading of typically brazilian cleavages. This concept will be fundamental to understand the concept of crucial difference in the chosen times and concepts.

Brazilian cleavages point out to a periodization where education was understood, first as systems, them as praxis, as history and as an instrument, so it is also a decisive point of cleavage the return and deepening of the teorical-metodological discussion of comparative education as a discipline. Nowadays, the actions of comparative societies in the world, the globalization phenomenon, the resurgence of the comparative method, and the return of comparative studies to the curricula of post-graduation, reactivate an epistemological and theoretical-methodological discussion in Brazil. It is a matter of sharing a reflection that considers these choices decisive in the development and consolidation of the field of comparative education in Brazil.

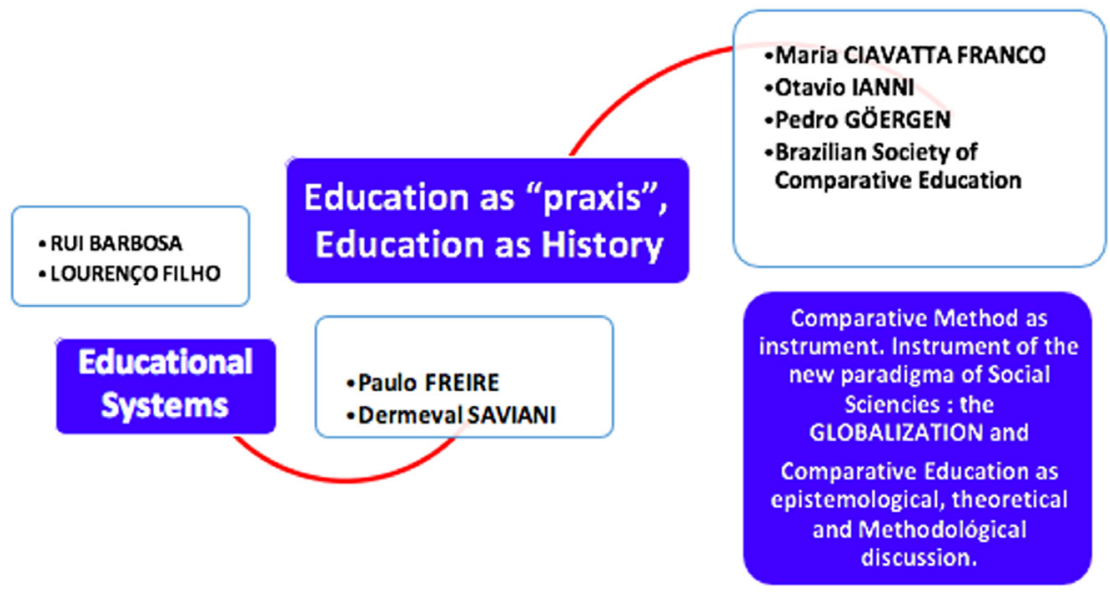

Chart 1: Trajectory of Comparative Education in Brazil.

The choosing of cleavage points can certainly be others, different from those we present here, because directed linked with the researchers' perspectives and senses. Ours are supported by the main aspects of education that were highlighted by each Brazilian author, and so it carries a local perspective, even if it also means to recognize that there are few references in the field; either because of the lack of references to reflect on, or because political groups in power could impose this look. Nevertheless, there are some importance to use national intellectuals once their choice to discuss education in a comparative way can also be understood as cleavage points, bringing new elements to the reflection.

The text distinguishes seven different moments when we link the comparative method and its resources of analysis, the historical method, the supranational and the supra-regional influences in the development of the field of comparative education in a historical perspective, which are: 1) the study of the structure and functioning of European and North American systems education; 2) the UNESCO's pioneering influence on the production of annuals; 3 ) the prioritization of educational practices; 4) the influence of supranational relations; 5 ) the focus on educational public policies; 6 ) new cycle of supranational influence; 7) (re)definition of the theoretical, methodological and epistemological anchorage of comparative education. All of them, treated individualized as follow.

\footnotetext{
${ }^{1}$ Although Lipset and Rokkan (1967) defined four basic cleavages for western civilization after the Industrial Revolution to identify voting blocs, for us the concept is used because of two aspects: a) the authors considered that voters opt for a certain party or decide for the solution or option that is closer to their own position in society; b) the drawing of this definition, once if parties are in a horizontal line for a certain issue, cleavage is the vertical line that divides the parties into supporters and opponents of this issue. In the Comparative Educational context, for us, in a periodization analysis there must be an adherence between the decisions about the moments highlighted that move the comparative analysis, with the researcher position in society and its theoretical, epistemological and methodological beliefs. In this scenario, the horizontal line are the years that the researcher choose to point as important dates, and the vertical lines indicate the moments that the researcher elected, in a way that they are all linked as forces that influence the events. For more, see AGUILAR, L.E. (2013)A política pública educacional sob a ótica da análise satisfatória. Ensaios, Campinas, SP, Edições Leitura Crítica.
} 


\section{MOMENT 1 THE STRUCTURE AND FUNCTIONING OF EUROPEAN AND NORTH AMERICAN EDUCATIONAL SYSTEMS}

In the first moment, Brazilian intellectuals, as well as Latin Americans, were concerned about the structure and functioning of educational systems in other countries, particularly the educational systems of Europe. The task demanded a significant comparative exercise, although some authors understand this perspective as a homogeneity, once it was dominated by the colonialism bias.

Most likely, the specific case of Rui Barbosa in $1883^{2}$ is a name of the Brazilian context that shares, with other intellectuals of that decade in Latin America, a simultaneous concern to equip countries with national education laws to reform national educational systems.

This affirmation is supported by the performance of Rui Barbosa as a congressman, proposing a set of educational reforms that approached to a national law of Education in Brazil, and whose attempt failed. In the same perspective, there is also the case of the Argentinian and French intellectuals, who in Buenos Aires, $1884^{3}$ and in Paris, $1883^{4}$ drafted and sanctioned their national laws of education.

Although with a local focus, is important to notice that the use of the simultaneity analysis strengthens the Brazilian case, once in the same time but different places there were movements worldwide on compulsion, secularism, gratuity, the right to public education and the role of the State.

It is also opportune to mention the figure of Lourenço Filho (2004) in Brazil, who identified the national education systems as an object of comparative education. In the preface to the second edition of Comparative Education of this author, one can read his concern with the purpose of knowing the world's educational systems, studying them orderly and descriptively accompanying them from analysis essays:

What is fair to expect from comparative education about student training is not only about technical rather than cultural aspects in general. As for the technical part, the comparative studies lead to relate concepts and instruments of analysis that are collected in many and varied sources, given the interdisciplinary nature of the subject. As for the cultural part, it is enough to remember that these studies are the most clearly situated in the different domains of pedagogical research, and in those who seek to elucidate situations on a macroeducation scale, in which the educational systems really present themselves. It will not be difficult for students, to admit the educational process as an integral problem of culture, by verifying their relations with the economic, political, religious and moral life of each people, and thereby to understand their possible implications for the social dynamics through intentional educational action, whose broader instrument is embodied in national education systems. (LOURENÇO FILHO, 2004 p. 9-10) (author's translation)5.

From the quotation, we can say that Lourenço Filho warns about the need to understand education as an integral phenomenon and multiple relationships, a situation identified in educational systems, which, despite being the background of plural interactions, are a sine qua non condition for their existence. With the book, the author establishes two new paradigms for the discussion of comparative education from the educational systems, namely: a) the assumption of systems as protagonists, but not for purposes in themselves; b) a new circuit of systems to be considered, in addition to Europeans and North Americans, since he also brings as examples Mexico, Argentina, Japan and India.

\footnotetext{
${ }^{2}$ For more information, see public documents about the elementary and high school reforms, higher education reform and from other complementary institutions presented to the Chamber by the congressman Rui Barbosa between 1882 e 1883. Also see CAMARA BASTOS, M.H. Ferdinand Buisson no Brasil - Pistas vestígios e sinais de suas idéias pedagógicas (1800-1900) in História da Educação ASPHE/FaE/ UFPel, Pelotas(8):79-109, set 00, and the Buisson report translated by Rui Barbosa. See also Rapport sur l'instruction primaire à l'Exposition Universelle de Philadelphie em 1876 de F. Buisson.

${ }^{3}$ See STORNI de OROZCO, M.M., Antecedentes Históricos y Caracteres de la Lei 1420/1884 in http://repositorio.educacion.gov.ar/dspace/ bitstream/handle/123456789/99617/Monitor_12040.pdf?s equence=1 access in oct. 2017.

${ }^{4}$ See Lei Ferry from 1879-1881 and 1882, about right to education, secularism and the State role in Education. Ferry, Jules François Camille, responded for the formulation of the law that creates the French educational public system, with its gratuity and secularism.

${ }^{5}$ Original Text: "O que é lícito esperar da educação comparada sobre a formação dos estudantes não diz respeito apenas a aspectos propriamente técnicos, mas culturais em geral. Quanto aos primeiros, os estudos comparativos levam a relacionar conceitos e instrumentos de análise que se colhem em muitas e variadas fontes, dado o caráter interdisciplinar da matéria. Quanto aos demais, basta lembrar que por esses estudos é que mais claramente se situam os diferentes domínios de investigação pedagógica e, em 10 Educação comparada especial, os que
} 
Despite Lourenço Filho being the only author that considered other role of systems to compare, is relevant to take in account that in the late 60's, the majority of Latin American countries and others with a lower rate of development, as India, would have already made a route approaching and resembling European and / or American educational systems. In this sense, using them as an option for comparison, can be understood or as a successful achievement led by the European and/ or American models, or as a closely historical and simultaneity example.

A later movement to distance themselves - Latin American countries - from those models by seeking their own identity occurred. We could affirm that it was a kind of post colonialism way to secure national identities, but it did not last much, another wave came to interfere locally. National economies and educational systems, as well as public services linked with fundamental rights suffered supranational influences with the globalization, strongly homogenizing management having the private system as model, teacher training and funding policies applying public money on public and private initiatives, and offering, simultaneously, an evaluation of these systems to have god results in less time. In Brazil, the new public management (NPM) was the proposal that set off this scenario.

Thus, the first moment we identify in Brazilian Comparative Education through a proposal of periodization is linked to the structure and functioning of European and / or American educational systems, and has two points of cleavage: 1) from 1880 to mid-century (1950-1960); and (2) between 1970 and 1990. The comparative look at other educational systems has shifted from one cleavage to another, from processes of organization of the structure and functioning of educational systems in formation and development, to obeying supranational logics.

Nowadays these logics are anchored in hegemonic economic fundaments of the central countries that end up guiding the general functioning of the educational systems in peripheral countries. As a result, they reoriented their educational systems because of the impact of the external debt burden and the prescriptive actions that the credit organisms imposed on the countries that contracted loans, such as was the case of the International Monetary Found (IMF) with Brazil in the late 90's.

\section{MOMENT 2 AND 3: UNITED NATIONS EDUCATIONAL, SCIENTIFIC AND CULTURAL ORGANIZATION'S PIONEERING INFLUENCE ON THE PRODUCTION OF ANNUALS AND THE PRIORITIZING OF EDUCATIONAL PRACTICES}

It can be said that there is a specific moment when the United Nations Educational, Scientific and Cultural Organization (UNESCO) starts to influence, and to demand, the production of annuals in the educational comparative field. But, once it is done by comparative exercises between different areas of interest and countries, additionally, it starts to prioritizing educational practices, how students learn and how teachers teach, which is the reason why we treat those moments together.

Taking Brazil as a reference, the UNESCO's influence moment originate in the end of the first and beginning of the second cleavage of the first moment. As an international organization, has the ability not only to do deep local researches, but also to put it all together in comparative categories, a step forward from the isolated discussion about the structure and functioning of educational systems ${ }^{6}$. In the other hand, simultaneously, the studies with a focus in educational practices were prioritized in the country because it fitted with the technicist education proposed by the government, inspired in the behaviorist learning theories between the 1960's and the 1970's.

The processes of dissemination generated from the production of annuals have been favoring the comparative exercise and designing a new agenda for the research area in universities and government agencies. It happened because UNESCO's annuals, since the second half of the 1940's, as well as those of multilateral organizations, revitalized this area of knowledge by providing not only the

busquem elucidar situações em escala de macroeducação, na qual os sistemas de ensino realmente se apresentam. Não será difícil, então, aos estudantes, admitir o processo educacional como problema integral de cultura, pela verificação de suas relações com a vida econômica, política, religiosa e moral de cada povo, e, desse modo, que compreendam suas implicações possíveis sobre a dinâmica social, através da ação educativa intencional, cujo instrumento mais amplo se corporifica nos sistemas nacionais de ensin. ${ }^{\circ}$ " (LOURENÇO FILHO, 2004 p. 9- 10). ${ }^{6}$ Although treating the moments in a periodization perspective, it does not mean that every new moment is an evolution compare to the previous one. Sometimes, like the one of UNESCO's in relation to the education systems, this affirmative is going to be truth; other times, it 
structure and organization of educational systems, their characteristics, but also some indicators of performance of each system, such as illiteracy, poverty, inequality and GDP.

Universities and national governement research improved once these annuals began to upgrade volume and specificity of the data they presented. Currently, UNESCO and regional agencies such as the Economic Commission for Latin America and Caribbean (ECLAC) and the Oficina Regional de Educación para América Latina y el Caribe (OREALC) have been able to include new analyzes by providing for old descriptive studies new analytical dimensions, modifying their own institutional agendas by overcoming annuals and formulating programs aimed at solving the main educational and social problems in the region.

The specific case of the Program for the Promotion of Educational Reforms in Latin America and the Caribbean (PREAL) ${ }^{7}$, to mention just one example, meets part of this reflection that traces the trajectory of the initial influence of the descriptive studies that induced descriptive comparisons for new compilations linked to Programs that aimed to promote reforms and solutions to educational and social problems. Both universities and governments in the Latin-American region have been particularly sensitive to the inevitable comparisons ${ }^{8}$ that emerge from these studies and compilations of international bodies. It is precisely in this sense that the agenda has been changing in the last 60 years, sometimes for the production of knowledge or for the presentation of this knowledge in the form of government policies and programs.

At the same time, in Brazil, an interest about teacher training, and how the students learn raised an intense comparative debate about the success and failure of governance in education. In the beginning the multilateral organizations focused the debate on the ideal models of teaching and learning to be followed or imitated; notwithstanding, even with the weakening of the technicist education in a behaviorist way, in 1990 we had theoretical talking about a neotechnicism related to the neoliberalism (FREITAS, 2011). The concept returns today with a new clothing for the privatization originated from the NPM (FREITAS, 2016), and Universities and Brazilian governments have been the central actors in choosing these models and their adoption without adaptation or changes, producing new alternative theoretical models.

Besides the influence of the educational practices, in Brazil is important to highlight the contributions of Paulo Freire (1968-) and Dermeval Saviani (1986-1996), which can be considered significant for the development of comparative studies in education because they provide differentiated readings of the idea of educational systems.

Freire (1964/1970) would go through the production of knowledge from a perspective that discussed learning from non-school experiences ${ }^{9}$, in the sense of being outside the educational system, with which would initiate a fundamental pedagogical discussion about a deep dimension of inclusion and exclusion.

Freire's perspective is a comparative reading of the other person, the question of the other as Ciavatta Franco $(1993)^{10}$ would point out, since he looked at them out of the conventional education system and thought them "from the outside in". There is his comparative wealth, made while the numerous trips during his exile, when from his writings allowed us to recognize education in Brazil considering the experiences in other lands.

\footnotetext{
is only a change of perspective.

${ }^{7}$ Chile PREAL is co-chared by the Inter-American Dialogue in Washington, D.C. and the Corporation for Development Research (CINDE), Santiago, Chile. It is funded by the United States Agency for International Development (USAID), the International Development Research Center (IDRC), Canadá, the Inter- American Development Bank (IDB), the GE Fund (GE Fund) and other donors.

${ }^{8}$ The PREAL program "Quedándonos atrás" (free translation: We are getting behind) - is a Report on Educational Progress in Latin America and brings a powerful repertoire of performance indicators about educational systems in the region inducing a comparative exercise with those considered paradigmatic.

${ }^{9}$ Freire's contribution to the reading of the question of the other in numerous works among which we have rescued as an illustration: Pedagogy of the Oppressed (1964), the intense studies on bilingualism in the 1970s that gave rise to Programs such as www.cepal.org/bialfa or records of their experience in Africa contained in the "Letters to Guinea-Bissau", 1978, among many others.

10 See more in CIAVATTA FRANCO, M.A. Quando nós somos o outro: Questões teórico- metodológicas sobre os estudos comparados na América Latina in Cadernos CEDES -Centro de Estudos Educação e Sociedade- América Latina: semelhanças e diferenças. N. ${ }^{\circ} 31$ Cedes Papirus, Campinas, 1993.
} 
The preoccupation with the literacy processes of the excluded has always, theoretically and methodologically, in Freire's, reconciled forms of learning to read and write the world from the perspective of the excluded and oppressed. Conceptually, it also redefined the praxis by endowing the literacy processes with a transformative potential of reality.

Saviani, Brought us a historical analysis of education, understanding it with history. Works such as "Para uma História da Educação Latino-americana" (1996) and "Desenvolvimento e Educação na América Latina" (1986) present inevitable comparative perspectives, as well as the discovery and understanding, from a historical perspective, of similarities and differences in a space and time shared in the emergence and later development of educational systems in Latin America ${ }^{11}$.

What seems significant since Saviani's contribution to comparative studies is his ability to systematize the history of education in Brazil by incorporating three decisive elements: education as history, legislation as structuring of national education, and analysis from historical-dialectical materialism. His contribution is related to comparative works such as Fernandez Lamarra (1986, of intense contribution to Ibero-American comparative education, which was also significant for the development of comparative studies in education in the relationship built between historical method and comparative method.

So, for the second and third moments we have three main points of cleavage. One, with two variations related to UNESCO's influence on the production of annuals, starting in the 1950's ${ }^{12}$ with descriptive researches presenting, besides the structure and organization of the educational systems, indicators of performance with a change in 1990 when they overcome annuals and start to formulating programs. The second, that is not fully separated from the first, with three variations that initiates in 1960 ending between 1980/1990, to continue in the 1990's and existing currently, where the prioritizing of educational practices are first linked with the technicist education, than with the neotechnicism and now a technicism for the private models of management. And the last one, considering the featured of Freire's and Saviani's researches in the educational field that are close to the comparative area, although getting into it in some very specific points.

\section{MOMENT 4 : THE INFLUENCE OF SUPRANATIONAL RELATIONS}

The 1990 decade is very important in Brazilian public policies history, and it reflects on the periodization of the comparative education field in the country, as we can notice so far, once some of the cleavage is related to this period.

Concerning to the fourth moment, with a new constitutional text, made in 1988 after a long dictatorial period, not only the fundamental rights and the democratic institutions began to bloom (ASSIS, 2012), but also the intensification of the international relations. Which does not mean that before there was not an international policy in Brazil, but it was very restricted, and with a protagonism from U.S.A.

Within this context, supranational relations influenced the educational comparative field, and the globalization process was decisive in the resurgence of the comparative method focused on the impact analysis, conquering an important spot in the academy.

In Brazil, during this period, there has been an intense discussion about Globalization as the new paradigm of social sciences. Ianni (1998) $)^{13}$, in the first half of the 1990s, presented us with a new epistemological challenge, which is to understand relations, processes and structures from the national society, understood as a classic paradigm of Social Sciences, for what was beginning to be designed as a global society, that concealed, assimilated, the national ${ }^{14}$.

\footnotetext{
${ }^{11}$ See SAVIANI, D., RAMA, G., WEINBERG, G. Para uma história da Educação Latino-americana, Campinas SP, Autores Associados, 1996 and also SAVIANI, D. RAMA, G., LAMARRA, N., AGUERRONDO, I. e WEINBERG, G., Desenvolvimento e Educação na América Latina, Cortes, 1986. To know more see SAVIANI, D., A pedagogia histórico-crítica.

${ }^{12}$ Is important to emphasize that the decades are indicate in terms of approximation.

${ }^{13}$ See IANNI, O., As Ciências Sociais na época na globalização. Rev. Bras. Ci. Soc., Jun. 1998, vol.13, n. ${ }^{\circ} 37$.

${ }^{14}$ It is important to note that although lanni's work "Globalização: Novo Paradigma das Ciências Sociais, Estudos Avançados 8(21) 1994 São Paulo, May/Aug" dates back to 1994, the author's reflections were already known in the early 1990s, and updated in 1998. To know more see AGUILAR, L.E.(2011) Desafios epistemológicos. A globalização no contexto das Ciências Sociais. 101-122 in A pesquisa da política pública educacional a partir da análise satisfatória [Research into Public Policy on Education based on Satisfactory Analysis], Tese de Livre Docência, Universidade Estadual de Campinas, São Paulo, Brasil, Dezembro.pp. 101-122.
} 
According to lanni (1998), It is essential to understand that social sciences have built up, during their epistemological development, reflections of empirical, methodological and historical nature on the space and time of the national society, however, in the end of the 1990, the author perceives the advance of global society on national society - which he translates as processes of assimilation -. Understands, also, the need to perceive the insufficiency of the reflections about global society - since they are based on a logic of national society - in order to create categories and concepts that might draw a new paradigm that contributes to the elaboration of explanations in this new reference scheme.

Concerning comparative education, special attention will be given to all the interpretations that have historically been made on this new object of the Social Sciences, as well as with their epistemological difficulties, one of which is linked to the method and the generalization of its use to all studies and interpretations.

(...) the comparative method evidently underlies practically all studies and interpretations. We compare nations and continents, technologies and goods, political regimes and government policies, economic, financial, political, social and cultural indicators, mixed state and private enterprise economies, market and planning. There are cases in which the comparison chooses relationships, processes, structures, seeking to combine synchronic and diachronic configurations. In other cases, indices, indicators, variables are compared. It is clear that the use of the comparative method is ultimately based on one of the theories mobilized for research: evolutionism, functionalism, systemic, structuralism, Weberian or Marxist. In general, the comparison takes as an open or implicit reference to this or that modern or developed country, industrialized, post-industrial country. (IANNI, 1998 p.6) ${ }^{15}$.

Ianni (1998) points out that the comparative method is, among others, an enigma to the social sciences, indicating that globalization phenomenon can be understood as the fuse to reborn the area, once it is a kind of self-scientific conscience of the social reality, with new challenges of interpretations. This rupture indicate a vital cleavage for a new development cycle in the comparative education field in Brazil.

\section{MOMENT 5 : THE FOCUS ON EDUCATIONAL PUBLIC POLICIES}

Educational systems were no less essential category to comparative education or comparative studies; however, after the 1990s, the protagonism came to be exercised by the public educational policies, understood as a set of state actions, at different deliberative levels by through which it is possible to know, analyze and evaluate a system.

The emphases at this moment 5 , are quite varied but are directly related to the previous moments. Ranging from policies of organization of the educational systems - coming closer to those studies of the first moment -, going through curriculum policies and evaluation policies, as a result of the influence of the 2nd and 3rd moments, to the financing policies - induced by the international scenario that outlined the 4th moment -, in a way that we often find comparative tests in documents of the international credit organizations.

It is also possible to affirm that this (re)signification ${ }^{16}$ of public policy in Latin America in the 1990s, from the semantic point of view, comes from an assimilation of the translation of public policy and, for this, we go back chronologically to the authors who recovered the term in the field of state administration, being the first to use it in the academy ${ }^{17}$.

\footnotetext{
${ }^{15}$ Original Text: Quarto, o método comparativo evidentemente está na base de praticamente todos os estudos e interpretações. Comparam-se nações e continentes, tecnologias e mercadorias, regimes políticos e políticas governamentais, indicadores econômicos, financeiros, políticos, sociais e culturais, economias estatizadas mistas e de empresa privada, mercado e planejamento. Há casos em que a comparação elege relações, processos, estruturas, procurando combinar configurações sincrônicas e diacrônicas. Em outros casos, comparam-se índices, indicadores, variáveis. É claro que o recurso ao método comparativo apoia-se, em última instância, em uma das teorias mobilizadas para a pesquisa: evolucionismo, funcionalismo, sistêmica, estruturalista, weberiana ou marxista. Em geral a comparação toma como referência aberta ou implícita este ou aquele país moderno, desenvolvido, industrializado, pós-industrial. (IANNI, 1998 p.6).

${ }^{16}$ The (re) signification was an important rhetorical strategy used during the 1990 s as a visible feature of favoring the introduction and assimilation of categories and concepts of a new liberalism that soon would gain academic status as neoliberalism. Public policy, management, quality and control, among others, are examples of this re-signification. A política pública, a gestão, a qualidade e o controle, entre outros, são exemplos desta ressignificação (AGUILAR, L.E., 1997, p.3).

${ }^{17}$ On the conceptual genesis of public policies and their analysis, we list authors drawn from AGUILAR VILLANUEVA, L.F. (Antologias de
} 
On the other hand, the recent influence of the American school on the study of public policies, coupled with the pressure of the international credit organisms, which govern the process of application and control of borrowed resources, may be bringing the discourses of forgetting these studies ${ }^{18}$ from the point of view of political and administrative theory and its resumption, with full force, specifically from the second half of the 1990s in Brazil, when the public policies category gains an academic status (DAGNINO, 2002) and becomes current discourse among managers of the federal, state and municipal spheres.

This moment can be understood as the new phase of comparative studies in Brazil, in order to stand out from moments 2, 3 and 4, since it brings together results that have occurred from the pressures and social changes that occurred during these other moments, once the (re)signification of public policies is related to the focus of global society, ranking the configuration and reconfiguration of the State and the Economy, whose main cleavage is the protagonism of a new object - public educational polices - in addition to the educational systems .

\section{MOMENT 6 NEW CYCLE OF SUPRANATIONAL INFLUENCE}

In the early 2000s, the Programme for International Student Assessment (PISA), promoted by the Organisation for Economic Co-operation and Development (OECD) ${ }^{19}$, supranationally institutionalizes an evaluation of students and educational systems that give rise to comparative goals that influence decisionmakers and public policies. At the global level, the practice recommends that local governments achieve more ambitious goals and encourages them to design and implement policies that make their educational systems comparable to others, in line with the new performance parameters and global scale.

In this scenario, what seems to be central in the reflection for the Brazilian case, is that the comparison induced by the performance indicators of the systems in the analytical sense of the disaggregated data of the educational systems was introduced in the daily life of the management of education at governmental level as well as in the daily life of school pedagogical projects. Both external evaluations and own evaluations of local governments have contaminated the learning processes and become a benchmark for the daily school life of managers, teachers and students.

If at the moment 3 the supranational institutions are present and strengthen the field of comparative education, they take advantage of the moment 4 that flexibilizes the borders between the countries due, in particular, to the technological advance and the configuration of the global society, in order to inaugurate a new supranational and supra-regional cycle of influence of these organizations in the evaluation of systems, students and teachers, giving indications of educational purposes to control its consequences.

This cleavage, different from moment 5 that presents public policies as a new element, is in fact a change

Políticas Públicas, volumes I, II, III e IV. México, DF: Grupo Editorial Miguel Angel Porrúa, 1993/1996) that places us, chronologically, as to the approach of this question by the academy: POPPER, Karl. The open Society and Its Enemies. London: Rutledge, 1945. SIMON, H. The administration Behavior. N.York: Free Press. 1945. LINDBLOM, Ch.: "The Science of Muddling Through". Public Administration Review, n.16. 1959. LOWI, Th.: "American Business and Public Policy Case Studies and Political Theory". World Politic, XVI, 1964. LINDBLOM, Ch.: "The Intelligence of Democracy”. N. York: Free Press, 1965. LINDBLOM, Ch.: The Policy Making Process". Englewood Cliffs, N.J.: Ed. Prentice-Hall, 1968. ALLISON, G.T. "Conceptual Models and the Cuban Missile Crisis". American Political Science Riview, LXII, n. 3. This article was edit as book in 1971. Essence of Decision Little Brown. Boston (trad. Esp. "La esencia de la decisión" Buenos Aires: Grupo Latinoamericano) 1969. ROSE, R. Policy-making in Britain. London: Macmillan, 1969. LOWI, Th.: "Four Systems of Policy, Politics and Choice". Public Administration Review. vol.32, 1972.QUADE, E.J. Analysis for Public Decision, N. York: American Elsevier (trad. esp. Análisis de formación de decisiones políticas. Instituto de Estudios Fiscales, Madrid, 1989) 1975. MAJONE, G.D.: "The Uses of Policy Analysis". In: The Future and the Past. Essays on Programs. Russell Sage Foundation. 1978. WILDAVSKY, A. Speaking Troth to Power, Little Brown. 1979. LINDBLOM, Ch. "Still Muddling, not yet through" Public Administration Review, 39, n. 4. 1979. ANDERSON, J.E. Public Policy- Making. 2a ed. N.York: Holt, Rinehort and Winston, 1984. / HOGWOOD., B.W.; GUNN, L.A.: Policy Analysis for the Real World. Oxford: Oxford University Press, 1984. LINDBLOM, Ch. The Policy Making Process. Englewood Cliffs, N.J.: Prentice-Hall, 1980. MAJONE, G.D.: Evidence, Argument and Persuasion in the Policy Process. New Haven, CT: Yale University Press. 1989. SUBIRATS, J.: Analisis de Políticas y Eficacia da Adminsitración. Madrid: Instituto Nacional de Administración Pública, 1989.

${ }^{18}$ See AGUILAR VILLANUEVA, L.F. La hechura de las políticas (1996, vol.II, p.15), which refers to the academic oblivion of the study of the process of policy making and justifies it with historical and theoretical reasons.

${ }^{19}$ PISA aims to assess to what extent students near the end of compulsory education have acquired some of the knowledge and skills for full participation in the knowledge society. PISA shows those countries that have achieved a good income while at the same time equitably distributing learning opportunities, thus helping to set ambitious targets for other countries. 
of focus, but not necessarily a new factor, demonstrating that, as far as supranational and supra- regional institutions are concerned, once originated in a comparative context, they adapt to it without great difficulties.

\section{MOMENT 7: THE (RE)DEFINITION OF THE THEORETICAL, METHODOLOGICAL AND EPISTEMOLOGICAL ANCHORAGE OF COMPARATIVE EDUCATION}

In a context of strong influence of the resurgence of comparative education in Brazil and a discussion of its epistemological and theoretical-methodological field, the university, both graduate and postgraduate courses, faces an intense comparative exercise of research that occurs independent of the recognition of what can be understood as Comparative Education.

In the Humanities and Social Sciences there is an intense proliferation of analyzes and comparative studies of educational nature not always attached to Comparative Education as a field of knowledge. In fact, this must be considered an epistemological field in permanent construction and its research forums may or may not agglutinate the intense production ${ }^{20}$ that is recorded. In the meantime, we must rescue a debate that may be the source of this understanding.

Göergen (1991) ${ }^{21}$ problematize the comparative method of education in discussing the obsolescence or actuality of comparative education and, in so doing, explicitly addresses fundamental epistemological issues that are present in the discussion between positivism and post-positivism in social sciences and the methodological strengths and weaknesses in the educational field.

For this reconstruction of scenario, we use three authors and their different, but complementary, perspectives. Göergen (1991), which addresses the problem of education and comparative method as a procedure that can be useful for the knowledge of other educational systems, its history, structure and problems, optimizing both the power of self-knowledge and the provision of subsidies for development of public educational policies. Ferrer $(2002)^{22}$, who brings the contribution to discuss the globalization and the future of the educational systems of the Nation-State. And finally, Nóvoa ${ }^{23}$ (1995-2000), which points out how the crisis of the school model was consolidated in the 19th century and, from this point of view, emphasizes that traditional comparative approaches must be replaced by historical reconstructions of a broad cultural spectrum, or by global analyzes of transnational interdependencies.

The historical recovery of Göergen's (1991) Comparative Education has global characteristics, in the scenario defined as a growing internationalization of knowledge and, in Latin America, highlights the eventual gains of mutual knowledge in the face of rapid regional integration processes in economics, sociology and literature and who seem to be embryonic in education. The author justifies,

Systematic, scientifically accurate and projected studies are lacking in the medium and long term. (...) The lack of an orderly research work is, in our view, the reason why Comparative Education can not live up to the expectations placed on it. In other words, we want to defend the thesis that the difficulties and lack of interest faced by the Comparative Education discipline stem from the lack of original research in the area (GÖERGEN, 1991 p.18 (authors translation) ${ }^{24}$.

Göergen (1991) makes a fundamental contribution to the development of Comparative Education in Brazil by making a historical retrospective of the discipline. However, from this analysis, we will rescue

\footnotetext{
${ }^{20}$ See CASTRO.M.S.de., Educação Comparada no Brasil: uma análise preliminar da produção acadêmica in http://revistas.unisinos.br/ index.php/educacao/article/view/edu.2013.173.06.

${ }^{21}$ GÖERGEN, P. L. Educação Comparada: uma disciplina atual ou obsoleta? Revista Pro-Posições, Campinas, Revista da Faculdade de Educação, vol. 2, n³, dez, 1991, p. 6-19.

${ }^{22}$ FERRER, F.J. La educación Comparada Actual. Barcelona: Editorial Ariel, 2002.

${ }^{23}$ NÓVOA, A. Modèles d'analyse en education compare: le champ et la carte, Les Sciences de l'Éducation. Centre d'etudes et de recherches en sciences de l'éducation de l'Université de Caen, n.2-3/1995, e também em catalão Estat de la questió de I 'educació comparada: paradigmes, avanços i impassos. Temps d'Educació, Universitat de Barcelona, n. 224, $2^{\circ}$, semestre, 2000.

${ }^{24}$ Original text: Faltam estudos sistemáticos, cientificamente acurados e projetados a médio e longo prazos. (...) A inexistência de um trabalho ordenado de pesquisa é, a nosso ver, a razão por que a Educação Comparada não consegue corresponder às expectativas nela depositadas. Em outras palavras, queremos defender a tese de que as dificuldades e a falta de interesse, enfrentados pela disciplina Educação Comparada, decorrem da falta de pesquisa original na área (GÖERGEN, 1991 p. 18).
} 
the author's concern about the value he will attribute to the great global systematizations ${ }^{25}$ and their inductive power over educational policies and their systems, anticipating, in decades, the political weight that would induce supranational organizations to determine the internal policies of states and educational systems. The value of these trends, announced by Göergen (1991), stems from the time of its formulation. In analyzing the question of method, it improves methodological recommendations of Lauwerys $(1961)^{26}$ and rekindles the debate on epistemological concerns.

If we admit that the comparative method used in education has a strong influence on sociology, statistics and empiricism, we will also accept, along with these influences, historical, geographical, economic, social and political contexts, among others, to account for the complexity of phenomena education. It includes the comparison of the comparable; the relationship between comparable data, decisions and political factors in the context. But, above all, it includes the fact that in the Brazilian and Latin American context, it is important to emphasize the contribution that it can bring to the solution of concrete educational problems and also the effort to give to the comparative studies, scientific character.

Göergen (1991) will reaffirm that since 1960 there has been a strong tendency to overcome external descriptive analyzes of educational systems and to bet decisively on the conditioning factors of the configuration of education systems and national education in general in function of the external constraints. We understand that it will reinforce the idea of complementary studies and interdisciplinar subjects that intersect in comparative analyzes, educational systems, educational policies, and macro and micro educational planning.

This overview is improved in terms of scope, with the approach of Holmes (1965) (problem approach) ${ }^{27}$. A combination of global comparative approaches (GÖERGEN, 1991) of educational systems and their problems is summarized in OECD evaluations, that condensates macro-educational analyzes of specific problems such as quality of education or student performance in standard assessments, so that both are not free from epistemological difficulties.

The idea is closer to Nóvoa (1995-2000), in order to understand that in the field of Compared Education there are groups of consensus theories (based on what is called social equilibrium) and conflict (based on the idea of social change), as well as descriptive approaches (based on observable phenomena and facts - as natural realities) and conceptual (observing facts as realities constructed by discourses).

Nóvoa's virtue lies in the fact that he systematizes theories and approaches from answers to the following questions: what comparison intends? which are your theories and your concepts? what are your goals and comparative units? and what are their practices and methods of comparison and how will they find and identify study perspectives? - which seems to us a contribution from the epistemological point of view. Thus it identifies Historicist Perspectives; Positivists; Moderns; Critics; and Socio-Historical.

\footnotetext{
${ }^{25}$ After the great difficulties resulting from the advance of national socialism, since 1933, and the outbreak of World War II, international cooperation in education has resurfaced with renewed force. The clearest manifestation of this desire to restart activities of cooperation and mutual knowledge was the creation of Unesco in 1946. In 1951, Unesco began the publication of the World Handbook of Educational Organizations and Statistics, which represents the great attempt to gather data and statistics on the most diverse educational systems in the world. The statistics service, animated by the idea of planning, had a retro-influence on the education systems themselves, which even improved or even created a system of statistics. Under the inspiration of UNESCO and the OAS, which was created in the United States and which also deals with educational problems, other institutes have been created. Today there are numerous Comparative Education centers in universities and research institutes all over the world. (GORGEN, 1991, p.9). Original Text: "Após as grandes dificuldades decorrentes do avanço do nacional socialismo, desde 1933, e a eclosão da Segunda Guerra Mundial, as atividades de cooperação internacional na área de educação ressurgiram com renovada força. A mais clara manifestação dessa vontade de reiniciar as atividades de cooperação e conhecimento mútuo foi a criação da Unesco em 1946. A Unesco iniciou, em 1951, a publicação do World Handbook of Educational Organizations and Statistics, que representa a grande tentativa de reunir dados e estatísticas sobre os mais diferentes sistemas educacionais do mundo. O serviço de estatísticas, animado pela ideia da planificação, teve retro-influência sobre os próprios sistemas de educação que passaram, inclusive, a aprimorar ou mesmo a criar um sistema de estatísticas. Sob a inspiração da UNESCO e da OEA, criada nos EUA e que também se ocupa de problemas educacionais, foram sendo criados outros institutos. Hoje existem inúmeros centros de Educação Comparada em universidades e institutos de pesquisa de todo o mundo" (GÖRGEN, 1991, p.9).

${ }^{26}$ GÖERGEN quotes LAUWERYS, J.A., "A Pedagogia Comparada: seu desenvolvimento, seus problemas". In: DEBESSE, M.; MIALARET.G. Tratado das Ciências Pedagógicas, vol.3, São Paulo, 1977, and about the same subject MONARCHA, C. e LOURENÇO FILHO, R. citam LAUWERYS, J. The philosophical approach to Comparative Education International. Review of Education, Hamburg, v.5, n.3, 1959 in Educação Comparada, 3a. Ed. INEP/MEC., Brasilia, 2004 (primeira edição em 1961).

${ }^{27}$ HOLMES, B. Problems in Education: A Comparative Approach. Londres, Routledge \& Kegan Paul, 1965 in GÖERGEN, op.cit.
} 
Ciavatta Franco (1990), Converging with Göergen (1991) and lanni (1994, 1998), contributes to the emergence and at the same time the strengthening of comparative studies in education. Her research, "Trabalho e sobrevivência - Política de Formação Profissional e gestão tripartite", held in Brazil, Mexico and Italy in the early 1990s, constitutes an important point of cleavage at this moment 7 , which, although beginning in the 20th century, is still underway.

The Brazilian experience of the researcher, allowed her to discuss the problems posed by the comparison and its use from the methodological point of view, juxtaposing perspectives of anthropology, political science, sociology, history and education, emerging a conceptual framework where history is understood as a process and method for highlighting analogies and specificities.

Ciavatta Franco's ${ }^{28}$ contribution would not only increase the theoretical-methodological debate of comparative studies in education, but also add elements for Latin American comparativeists to enrich their analyzes, in addition to the global economic transformations and their impacts, from the asymmetries, temporal of the three countries, their national and cultural constructions.

Thus, a favorable situation would mean that the comparative studies in Brazil reached an institutional dimension, with the creation of the Brazilian Society of Comparative Education -SBEC- in $1983^{29}$.

The national context of the institutional transformations originating from the redemocratization of Brazil, as well as the influence of the national associations of researchers that strengthened the analysis of the situation of the educational systems and the national congresses of these associations, encouraged a process of association. That met the wills of the teachers and researchers of the area, established principally in Rio de Janeiro and Brasília - its founders - and would expand nationally and internationally, what can be seen as a product of the same exercise of comparative research.

It stands out as a singular fact of the performance of a society that brought together comparative educators that does not collide with the vast universe of academic production of research in education considered to be comparative; or that rehearses comparisons or which theorizes and research comparatively or even those studies that are comparative, but are not registered in databases as included in this research field. All coexist to this day producing quantitatively and qualitatively rich collections of comparative research published in national and international annual congresses ${ }^{30}$, biennials with frequency and regularity being disseminated in conventional and digital media.

In this sense, the plurality of points of view on comparative education marks the moment 7 as a point of cleavage, for although comparative education as a research area is currently consolidated in Brazil, it cannot be understood as the only convergent of the discussions on comparative research. The complexity of the analysis of the current period is much greater than those identified in earlier moments in which some clear emphasis could be placed with some certainty.

\footnotetext{
${ }^{28}$ See When we are the other: Theoretical-methodological questions about comparative studies in Latin America CIAVATTA FRANCO, M.A. Quando nós somos o outro: Questões teórico-metodológicas sobre os estudos comparados na América Latina in Cadernos CEDES -Centro de Estudos Educação e Sociedade- América Latina: semelhanças e diferenças. N. ํ 31 Cedes Papirus, Campinas, 1993.

${ }^{29} \mathrm{https}$ ://www.sbec.fe.unicamp.br.

${ }^{30} \mathrm{~A}$ contribution to the field of comparative studies in Brazil is also in the recent International Seminars organized by CAPES (2012-2014), the Brazilian agency for the evaluation and financing of the postgraduate system.
} 


\section{DISCUSSION AND CONCLUSIONS}

\section{The dynamics of a panorama: conclusions that do not close the discussion}

Here follows a summary table with the moments and the cleavages in highlights once the proposal, in this text, is of a reading from the periodization. Many others can be made and present different results, since the moments and the cleavages are related to the options of the researchers.

\begin{tabular}{|c|c|c|}
\hline MOMENTS & CLEAVAGE POINTS & YEARS \\
\hline \multirow{2}{*}{1} & Educational systems (process and organization) & $1880-1950 / 1960$ \\
\hline & Educational systems (structure and functioning) & $1970-1990$ \\
\hline \multirow{6}{*}{2 and 3} & UNESCO's influence (annuals) & $1950-1990$ \\
\hline & UNESCO's influence (programs) & 1990 - currently \\
\hline & Educational practices (technicist education) & $1960-1980 / 1990$ \\
\hline & Educational practices (neotechnicist education) & $1990-2000$ \\
\hline & Educational practices (private technicist education) & 2000 - currently \\
\hline & Freire's and Saviani's research & 1970/1980 - currently \\
\hline 4 & Suprantional relations (global society) & 1995 - currently \\
\hline 5 & Public Educational Policies and Educational Systems & 1995 - currently \\
\hline 6 & New cycle of supranational influences (indicatiors) & 2000 - currently \\
\hline 7 & theoretical, methodological and epistemological pluralism & 1990 - currently \\
\hline
\end{tabular}

Chart 2: Moments and Cleavage points in the Trajectory of Comparative Education in Brazil.

Moreover, in our understanding, periodization essays on comparative education must proliferate because this is our purpose. We do not deliberately exclude names or periods, we only choose points of cleavage that can be a pretext for deepening discussions and strengthening academic debate by recognizing ourselves through others and others looking at our history of education and our present, for this construction of comparative education in Brazil mirrors domestic national movements and supranational movements that constitute the main pretext of education analysts, policy analysts and educational systems. 


\section{BIBLIOGRAPHIC REFERENCES}

AGUILAR VILLANUEVA, L.F. (1996). La hechura de las políticas (Antologias de Políticas Públicas, volumes I, II, III e IV. México, DF: Grupo Editorial Miguel Angel Porrúa, 1993/1996.

AGUILAR, L.E. (1997) La gestión de la educación: su significado a partir de propuestas pedagógicas institucionales III Congresso Latino-Americano de Administração da Educação -21-25 de Julho, Univ. Estadual de Campinas, UNICAMP, São Paulo, Brasil.

AGUILAR, L.E. (2011) Desafios epistemológicos. A globalização no contexto das Ciências Sociais. 101-122 in A pesquisa da política pública educacional a partir da análise satisfatória [Research into Public Policy on Education based on Satisfactory Analysis], Tese de Livre Docência, Universidade Estadual de Campinas, São Paulo, Brasil, Dezembro.pp.101-122.

AGUILAR, L.E. (2013) A política pública educacional sob a ótica da análise satisfatória. Ensaios, Campinas, SP, Edições Leitura Crítica.

ASSIS, A.E S., (2012) Direito à educação e diálogo entre poderes, Universidade Estadual de Campinas, São Paulo, Brasil, julho.

CASTRO.M.S.de. (2013) Educação Comparada no Brasil: uma análise preliminar da produção acadêmica in http://revistas. unisinos.br/index.php/educacao/article/view/edu.2013.173.06

CIAVATTA FRANCO, M.A. Quando nós somos o outro: Questões teórico-metodológicas sobre os estudos comparados na América Latina in Latin America in Cadernos CEDES -Centro de Estudos Educação e Sociedade- América Latina: semelhanças e diferenças. N. ${ }^{\circ} 31$ Cedes Papirus, Campinas.

FERRER, F. J. (2002) La educación Comparada Actual. Barcelona: Editorial Ariel.

FERRY, J. (1882) Education Act of 28 of March 1882. Lei Ferry de 1879-1881 e 1882, sobre Direito à Educação, laicidade e papel do Estado na Educação. Ferry, Jules François Camille, que respondera pela formulação da lei que criaria do sistema educacional francês de ensino público, sua gratuidade e laicidade.

FREITAS, L.C. (2011) Responsabilização, meritocracia e privatização: conseguiremos escapar ao neotecnicismo? In: Seminário de Educação Brasileira, 3., Centro de Estudos Educação e Sociedade, Campinas, fev.

FREITAS, L.C. (2016)Tecnicismo, ele está de volta. In: https://avaliacaoeducacional.com/2016/08/26/tecnicismo-ele-esta-de-volta/ 2016.

GÖERGEN, P. L. (1991) Educação Comparada: uma disciplina atual ou obsoleta? Revista Pro- Posições, Campinas, Revista da Faculdade de Educação, vol. 2, n³, dez, p. 6-19.

HANS, N. (1949) Comparative Education - A Study of Educational Factors and Traditions. Londres: Routledge \& K.Paul ed. In: GÖERGEN, op.cit.

HOLMES, B. (1965) Problems in Education: A Comparative Approach. Londres, Routledge \& Kegan Paul, in GÖERGEN, op.cit.

IANNI, I., (1994) Globalização: Novo Paradigma das Ciências Sociais, Estudos Avançados 8(21) São Paulo, May/Aug.

IANNI, O. (1998) As Ciências Sociais na época na globalização. Rev. Bras. Ci. Soc., Jun. vol.13, n. 37.

KANDEL, I. L. (1933) The Outlook in Education. - One of the Joseph Payne Lectures for 1932- 33, London: Oxford University Press, In GÖERGEN op.cit.

KAZAMIAS, A. M.; MESSIALAS, B. G. (1965) Tradition and Change in Education - A Comparative Study. Englewood Cliff, N.J., Prentice-Hall.

LIPSET, S. M., \& ROKKAN, S. (1967). Cleavage Structures, Party Systems and Voter Alignments: An Introduction. In S. M. Lipset \& S. Rokkan (Eds.), Party Systems and Voter Alignments: Cross-National Perspectives. New York: Free Press.

LOURENÇO FILHO, M. B. Educação Comparada (2004) org. Ruy Lourenço Filho \& Carlos Monarcha 3 ed. Brasília MECl Inep, recuperando as edições, 1a, 2a 3a da obra de Lourenço Filho desde 1963.

NÓVOA, A. (2000) Modèles d'analyse en education compare: le champ et la carte, Les Sciences de l'Éducation. Centre d'etudes et de recherches en sciences de l'éducation de l'Université de Caen, n.2-3/1995, See Estat de la questió de I 'educació comparada: paradigmes, avanços i impassos. Temps d’Educació, Universitat de Barcelona, n. $224,2^{\circ}$, semestre.

OCDE - O Programa para a Avaliação Internacional de Alunos da OCDE - PISA - (OECD Organization for Economic Co-operation and Development - Programme for International Student Assessment - PISA).

OREALC. (2001) Programa de Promoción de la Reforma Educativa en América Latina y el Caribe (PREAL) - "Quedándonos atrás", Santiago de Chile, Chile.

RUI BARBOSA, (1947) Pareceres de Reforma do Ensino Primário, Secundário e Superior e de várias instituições -1882 e 1883- in Obras Completas de Rui Barbosa, Rio de Janeiro, Ministério de Educação e Saúde.

SCHNEIDER, F. (1961) Vergleichende Erziehungswissenschaft - Geschichte Forschung. Lehre, Heidelberg, In: GÖERGEN op.cit. 
SKOCPOL, T.; SOMERS, M., (1979) Los usos de la Historia Comparativa en la investigación Macrosocial. Asociación Americana de Sociología, Boston, Massachussets, Agosto.

STORNI de OROZCO, M. M. (2016) Antecedentes Históricos y Caracteres de la Ley 1420/1884 in http://repositorio.educacion.gov.ar/dspace/bitstream/handle/123456789/99617/Monitor_12040.pdf?sequence=1 acesso julho de 2016.

UNESCO (1951) World Survey of Education. Handbook of Educational Organizations and Statistics. Paris. 